Wochenschrift. His lectures, which attracted numerous specialists from both his own and foreign countries, were remarkable for their clearness and precision, and many of his pupils afterwards occupied chairs of dermatology in different countries. Throughout his life he upheld Hebra's teaching, including the erroneous doctrine of the identity of chicken-pox and small-pox, and of measles and German measles. $\mathrm{He}$ died on March 16, 1902, a few days after the celebration of the twenty-fifth anniversary of his appointment as professor.

\section{Compton Manor Estate: Veterinary Field Station}

THE recent announcement that the Agricultural Research Council has purchased from Mr. Alfred Barclay the Compton Manor Estate on the Berkshire Downs will be welcomed by farmers and others having an interest in the well-being of agriculture and particularly the livestock side of the industry. In addition to the purchase of the land, the Council has arranged to buy the well-known pedigree herds of Ayrshire, Friesian and Guernsey cattle and also the herd of Large White pigs. A field station is to be established at Compton Manor primarily for investigation of problems of animal health and disease. Farmers, veterinarians and all workers in any branch of animal husbandry or nutrition will agree that a development of this nature is long overdue. Material advance has been made in recent years in our knowledge of the breeding and feeding of farm livestock, and while admitting that important advances in the diagnosis, prevention and treatment of many diseases have been made, it is unfortunately only too true that there are still diseases, of wide incidence and causing enormous loss, of which very little is known in the way of treatment. Until these diseases can be controlled or cured, the potential gain which could be derived from the existing knowledge of nutrition and breeding is very seriously curtailed. The Council's announcement mentions two such diseases on which it is proposed work should commence immediately, namely, contagious abortion in cattle and fowl paralysis in poultry stocks. A bad attack of either may seriously interfere with progress which has been made over years of constructive breeding and successful feeding and management.

IN the investigation of diseases, the initial work must be carried out in research laboratories and then on small animals, but a stage comes when the results must be tried out on farm animals and under normal farm conditions. Facilities for this field work, while not non-existent, have been extremely limited in the past, and the creation of a field station for this specific purpose will help to bridge this gap. The field station will allow methods of treatment or control apparently successful in the laboratory to be tried out under practical conditions before being passed on to the farmer or practising veterinary surgeon. Another object in the establishment of the station is that it will be able to supply to other research institutes, for experimental purposes, farm animals of known history and free from disease. This service will bridge another gap; and in addition to increasing the opportunities for work at existing research institutes, it will help to maintain the desirable collaboration between those institutions and the new station. The Council states it does not wish to set up a self-contained research institute, and hopes that, in addition to other methods of collaboration, existing institutes will second members of their staff to work at Compton on some problem when it would appear that the station is the most suitable place for joint work. All agriculturists, whether farmers or research workers, will watch with great interest the development of this new station, and wish it success in the important work which it is undertaking.

\section{German and British Lantern Slides}

A CORRESPONDENT writes: "Those who, during recent years, have attended lectures on scientific subjects in Germany will have been favourably impressed by the well-made, dignified lantern slides which are used there. In many cases, the slides are made with different colours to indicate the various curves or other significant portions of diagrams. Sometimes they have coloured arrows pointing to special details. The lantern slides are generally produced to a standardized system, so that time and mental energy are saved in knowing where to look for the title, date of preparation and other significant features. This year it was noticed that some of these lantern slides were made by the Technisch.Wissenschaftliches Lehrmittelzentrale, Berlin N.W.7, Dorotheenstr.32. There would appear to be no organization in England corresponding to this technical science teaching equipment centre and it is probably true to say that lecturers in this country generally use lantern slides less satisfactory than those seen in Germany. It is suggested, therefore, that it would be to the benefit of technical education in England if encouragement could be given to the production of high-class lantern slides in this country, through the Board of Education, organizations of technical teachers and similar bodies. In this manner they would assist technical education both from the point of view of the lecturer and of the student."

\section{Lectures and Demonstrations at the Zeiss Works}

NINE hundred scientific workers, including no fewer than 160 non-Germans, attended the second Zeiss-Kurs in Jena last month. As apparently only three Englishmen were present, it would appear to be worth recording that many German firms sent several representatives to this three-day course of twelve lectures, at which more than two hundred instruments were set out, to be demonstrated by between fifty and sixty experts. On one evening during the course, a performance was given in the Zeiss Planetarium. The first day was devoted to microscopy and metallography, the lecturers being Prof. Hanemann (speed of alloy transformations); Prof. Pomp (causes of failure in the working of iron and steel); Dr. Scheil (theory of hardening steel) and Dr. Hansen (light metals and their uses). The second day's lectures dealt with spectro-analysis and photometry, the lecturers being Prof. Gerlach (progress in spectro-analytical methods); Dr. Ginsberg 
(new photometrical methods in light metal analysis); Dr. Ramb (various spectro-analysis investigations for industrial laboratories) and Dr. Kaiser (contributions to the spectro-analysis of light metal alloys). The third day's work was on fine measuring, the lecturers being Prof. Kienzle (means of obtaining reliable dimensional data regarding machine com. ponents); Dipl.-Ing. Claassen (supervision of gear wheel manufacture); Dr. Berndt (testing of gear teeth) and Herr Nichterlein (modern developments in projection as a means of measuring).

\section{Engineering and Transport}

IN his presidential address to the Institute of Transport on October 11, Sir Alexander Gibb suggested that we are on the threshold of another great advance in methods of transport. He did not speak of the experiments that the great physicists of the world are carrying out in their laboratories; he confined himself to consideration of the most that engineers can offer, to improve transport with the knowledge and means they have at present. In constructing bridges, the record for length $(4,200$ feet) is held by the Golden Gate Bridge at San Francisco. He said that American engineers are confidently looking forward to building, within the next ten years, spans up to 10,000 feet long. With present materials and the development of wire cable construction, it is quite possible to expand this length to 18,000 feet; but before this limit is reached, the ratio of dead load to live load would be too great to make spans of this length economically justifiable. In air transport the speeds at which aeroplanes will regularly operate will before many years equal or exceed the highest speed records at the present time, and the distances over which they will operate will be greatly extended. Sir Alexander doubts, therefore, whether floating seadrome bases or mother seaplane ships will over be necessary for great ocean crossings.

At the moment, road design is the most urgent of the problems of transport engineering. It is purely a matter of policy and economics whether Great Britain should endeavour to develop road systems like those in Germany. In Great Britain there are 41,000 miles of road subject to the 30 m.p.h. restriction; and more than half the Great North Road is only suitable for two-line traffic, although we have the greatest density of motor traffic on the roads of any country in the world. Germany recently in one year spent 25 million pounds on entirely new road construction, and in 1935 the United States spent about 120 million pounds. In Great Britain the building of a new road is a rare event. A complete programme of new trunk motor roads in Great Britain, connecting all the principal towns, might cost up to a thousand million pounds. A further attempt to solve the traffic problems of London in the way that New York is dealing with its difficulties, on the lines of the regional plan of 1929, with its forty years programme, involving about 1,700 miles of parkways, boulevards, etc., would cost more. It might even not be possible. Sir Alexander pointed out that these are not exclusively engineering problems. They must be examined from the economic point of view before a decision can be reached.

\section{The Hanseatic Scholarships}

IT is announced in The Times that a Hamburg merchant, who desires to remain anonymous, has created out of his private means a fund to provide in the first instance not fewer than four scholarships annually, each of the value of 3,000 Rm., for young British graduates who desire to study in Germany. These scholarships are to be known as the Hanseatic Scholarships. They will be tenable for one year, may be held in any subject, and will be open to all students of the universities of the British Empire, with a preference for students from Great Britain. The founder hopes that the Hanseatic Scholarships may help "to further closer relations and understanding between the German and British peoples and to promote a consciousness of European solidarity". The trust, of which the first patron is the German Ambassador at the Court of St. James's, will be assisted in the selection and guidance of the scholars by a German and a British committee. The British committee, as so far constituted, will consist of : Lord Lothian (chairman), Dr. W. G. S. Adams, Prof. E. D. Adrian, Dr. George Gordon, Sir Henry Tizard, and Prof. H. G. Fiedler (secretary), professor of German language and literature, University of Oxford, from whom further particulars may be obtained.

\section{Association of British Chemical Manufacturers}

TwENTY-ONE years of activity were reviewed by the chairman, Mr. Eben Wallace, at the annual general meeting, held on October 14, of the Association of British Chemical Manufacturers, which was formally incorporated on December 28, 1916. The initial membership was 110 firms, representing a capital of $£ 39,000,000$, whereas now, although the actual membership has not shown any great increase,

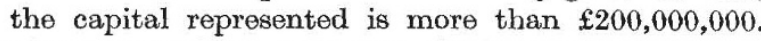
The Association's directory, "British Chemicals and their Manufacturers", was first published in 1919, and a new edition has since been issued every second year. $1920 \mathrm{saw}$ the formation of the British Chemical Plant Manufacturers' Association, whilst in 1927 the Association's Works Technical Committee commenced its work on safety in the chemical industries. Other activities have been concerned with fiscal matters, with the setting up of standards, with the organization of exhibitions, with the incidence of legislation, and, generally, with the promotion of co-operation within and around the industry. The annual report refers to the Association's activities, during the year ended May 31 last, in relation to the new Factories Act and other legislation, to the work of the Import Duties Advisory Committee, to commercial treaties, to safety measures, to the fund which the chemical industry has established in support of chemical publications and library facilities, to trans. port, and to various other relevant matters. Dr. F. H. Carr was elected president of the Association, and Mr. E. V. Evans and Mr. R. Duncalfe respectively chairman and vice-chairman of the council. 